\title{
Aktivitas Harian Bekantan (Nasalis larvatus Wurmb) di Hutan Karet Kabupaten Tabalong, Kalimantan Selatan
}

\section{Daily Activities of the Proboscis Monkey (Nasalis larvatus Wurmb) in Rubber Forest of Tabalong District, South Kalimantan}

\author{
Mochamad Arief Soendjoto ${ }^{*}$, Hadi Sukadi Alikodra ${ }^{2}$, Muhammad Bismark ${ }^{3}$, Heru \\ Setijanto ${ }^{4}$
}

${ }^{1}$ Fakultas Kehutanan Universitas Lambung Mangkurat (UNLAM), Banjarbaru 70714

Telp./Fax: 62-511-4772290, Email: asoendjoto@telkom.net*Penulis untuk korespondensi

${ }^{2}$ Fakultas Kehutanan Institut Pertanian Bogor (IPB), Bogor 16680

${ }^{3}$ Pusat Penelitian dan Pengembangan Hutan dan Konservasi Alam, Departemen Kehutanan, Bogor 16118

${ }^{4}$ Fakultas Kedokteran Hewan Institut Pertanian Bogor (IPB), Bogor 16680

\begin{abstract}
The daily activities of the proboscis monkey (Nasalis larvatus Wurmb) living in rubber forests are poorly understood. The objectives of the research were to study its daily movement pattern and to determine the time proportion of daily behaviors. The movement of the monkeys was followed by researchers on foot. The behaviors were observed by scan technique in $\mathbf{1 5}$ second intervals for $\mathbf{3 0}$ minutes. In rubber forests, lowlands (baruh) were places where the monkey began and ended daily movements and also conducted most activities. Most inter-water movements of the monkey (about $70 \%$ ) were conducted twice a day. Statistically, movement distance and rainfall were negatively and significantly correlated $\left(I_{s}=-0.58 ; p<0.05 ; n=14\right)$. The monkey spent more time for feeding in the morning and afternoon, and resting at midday. Most behaviors of feeding, resting, playing, and grooming $(\mathbf{8 4 . 0 1 \%})$ were conducted at a tree height of less than $15 \mathrm{~m}$. The monkeys moved farther during the dry season to get water and did activities in accordance with height strata to get various foods, avoided disturbances, and got comfortable and safe places.
\end{abstract}

Keywords: proboscis monkey, rubber forest, movement, daily activity, lowlands

Diterima: 21 September 2005, disetujui: 03 Maret 2006

\section{Pendahuluan}

Bekantan (Nasalis larvatus Wurmb) merupakan primata dwi-rupa kelamin (sexual dimorphism) dan endemik Borneo (Kalimantan, Brunei, Sabah, Serawak). Primata yang digolongkan rentan oleh IUCN, dimasukkan ke dalam Apendiks I CITES, dan dilindungi peraturan perundang-undangan Pemerintah RI ini telah ditetapkan sebagai fauna identitas Provinsi Kalimantan Selatan berdasarkan Surat Keputusan (SK) Gubernur Kepala Daerah Tingkat I Kalimantan Selatan No. 29 Tahun 1990 tanggal 16 Januari 1990.
Di Kalimantan Selatan, bekantan diketahui menghuni tipe habitat, yang berupa hutan mangrove, hutan campuran di tepi pantai, di sepanjang atau di muara sungai, hutan rawa gambut, hutan rawa yang didominasi galam Melaleuca cajuputi, hutan yang tumbuh di atas bukit kapur, serta hutan karet Hevea brasiliensis. Di habitat tersebut primata endemik Borneo ini melakukan aktivitas harian, baik yang dilakukan secara individu maupun dalam kerangka interaksi sosial. Secara umum aktivitas harian mencakup berpindah dari tapak tertentu ke tapak lain atau menetap di tapak tertentu selama waktu tertentu dan selanjutnya melakukan kegiatan 
makan, istirahat, bermain, menyelisik, atau aktivitas lain. Tujuan utama beraktivitas adalah untuk mempertahankan hidup.

Beberapa publikasi penelitian telah mengungkap aktivitas bekantan di tiga tipe habitat. Bismark (1986b), Alikodra dan Mustari (1994), dan Soerianegara et al., (1994) mengungkap aktivitas harian bekantan di hutan mangrove, Yeager (1989) untuk bekantan di hutan rawa gambut, serta Salter et al., (1985) dan Bennett dan Sebastian (1988) untuk bekantan di hutan muara sungai atau tepi pantai. Sementara itu, publikasi yang berkaitan dengan aktivitas harian di hutan galam, hutan yang tumbuh di atas bukit kapur, dan hutan karet masih belum ada.

Penelitian dilakukan untuk mengungkap aktivitas harian bekantan di hutan karet. Hutan karet yang dijadikan sampel terletak di Desa Simpung Layung, Kecamatan Muara Uya, Kabupaten Tabalong. Tujuan penelitian secara spesifik adalah mengetahui pola perpindahan bekantan serta menduga proporsi waktu perilaku hariannya.

\section{Metode Penelitian}

Pengumpulan data dilakukan antara jam 06.00 dan jam 18.00 pada periode April 2003 Juli 2004; jumlah waktu pengamatan 2.224 jam. Berdasarkan pada pengamatan pendahuluan terhadap perilaku bekantan, aktivitas harian primata ini terdiri atas aktivitas pokok yang berupa berpindah atau menetap. Berpindah merupakan upaya kelompok atau subkelompok untuk berpindah dari sumber air tertentu ke sumber air lain; sumber air yang dimaksud dapat berupa sungai atau baruh. Menetap adalah upaya kelompok atau subkelompok (setelah berpindah dari sumber air tertentu atau sebelum berpindah ke sumber air berikutnya) untuk tetap berada di dekat atau di sekitar sumber air pada waktu tertentu.

Perpindahan bekantan diikuti oleh peneliti dengan jalan kaki melalui jalan setapak yang ada di hutan karet atau menerobos hutan secara perlahan-lahan agar bekantan tidak terganggu. Parameter yang didata adalah jarak, durasi, waktu, dan frekuensi perpindahan harian. Jarak diperhitungkan dalam kelipatan $25 \mathrm{~m}$.

Selama bekantan menetap, perilaku berikut ini (kriteria dimodifikasi dari Soerianegara et al., 1994) diamati.

1. Makan: kegiatan meraih pakan, membawa, memasukkan ke mulut, mengunyah, dan (mungkin) membuang atau melepaskan pakan yang dipegang anggota tubuh (tangan, kaki).

2. Istirahat: duduk, berdiri, berbaring di tempat, atau berjalan (bergeser) sekedarnya di sekitar tempat tersebut, tanpa melakukan kegiatan lain.

3. Bermain: bergerak dengan tujuan takterarah, baik dilakukan sendirian atau bersama dengan individu lain.

4. Menyelisik (grooming): menggaruk atau mengambil sesuatu dari bagian-bagian tubuh diri sendiri atau individu lain dengan mulut, tangan, atau kaki.

Pengamatan dilakukan dengan metode scan technique (Martin \& Bateson, 1987) pada interval waktu 15 detik selama 30 menit. Untuk memfokuskan pengamatan terhadap obyek dan meningkatkan ketelitian,

1) jumlah individu bekantan yang diamati maksimum empat ekor,

2) satu individu diamati untuk satu perilaku.

Selama berperilaku, pemanfaatan ruang secara vertikal atau menurut strata pohon dicatat. Strata pohon diklasifikasikan ke dalam tinggi 0-5, 5-10, 10-15, dan 15-20 m. Pohon yang tingginya lebih besar dari $20 \mathrm{~m}$ dimasukkan ke dalam kelas 15-20 m, karena jumlah pohon demikian sangat jarang.

Perilaku (makan, istirahat, bermain, menyelisik) selama bekantan berpindah, tidak diamati. Pengamatan sulit dilakukan, ketika bekantan berpindah. Pandangan peneliti sering terhalang oleh bagian tetumbuhan. Selain itu, bekantan pun tidak berdiam cukup lama pada tapak tertentu.

Data yang berkaitan dengan perilaku dianalisis secara deskriptif (rerata, kisaran, prosentase) dan pada beberapa kasus diuji dengan uji $\chi^{2}$. Korelasi antara jarak perpindahan harian dan curah hujan ditentukan dengan korelasi Spearman. Data curah hujan merupakan data sekunder dan diperoleh dari stasiun penangkaran hujan di Muara Uya; 
stasiun ini merupakan stasiun terdekat yang jaraknya 3-4 km dari lokasi penelitian. Untuk melengkapi pembahasan, hasil penelitian dibandingkan dengan hasil penelitian yang sudah dipublikasikan.

\section{Hasil dan Pembahasan}

\section{Perpindahan Antar-Sumber Air}

Terdapat lima kelompok bekantan di hutan karet Desa Simpung Layung. Bekantanbekantan ini menghuni dua bagian hutan, yaitu Hutan Simpung (HS) dan Hutan Mabai (HM). HS adalah bagian hutan yang terletak di selatan jalan tanah Simpung - Ojik dan HM adalah bagian hutan di utara jalan tanah tersebut. Jalan tanah selebar 5-7 $\mathrm{m}$ yang baru dibangun pada tahun 2000 itu memanjang dari barat ke timur dan menghubungkan jalan Simpung Layung Muara Uya dengan jalan Trans Kalimantan sisi timur (Banjarmasin - Balikpapan).

Di hutan karet terdapat sumber air, berupa belumbang, baruh, dan sungai kecil. Belumbang adalah hamparan lahan yang turun (ambles) setelah pelapukan akar dan digenangi air. Baruh serupa dengan belumbang, tetapi berukuran lebih luas. Sebagian baruh merupakan bagian dari sungai atau dapat mengalirkan airnya ke tempat lain yang permukaannya lebih rendah. Baruh di lokasi penelitian yang dikenal masyarakat sekitar adalah Ari, Munti, Puak, Saga, Rantaubaru, Nunuk, Bukuan, dan Panai Buruk. Baruh lain tidak bernama. Untuk memudahkan penelitian, beberapa baruh dinamai Simpung-1, Simpung2, Simpung-3, Mabai-1, Mabai-2, dan Mabai-3. Beberapa baruh dihubungkan dengan sungai kecil, yaitu Sungai Maliu selebar 0,5-3,5 m dan bermuara di Sungai Uwi.

Sumber air (dalam pengertian ini termasuk wilayah bervegetasi atau wilayah daratan dalam jarak $100 \mathrm{~m}$ dari tepi sumber air) merupakan bagian habitat penting bagi bekantan. Berdasarkan pada perjumpaan dengan bekantan di 18 lokasi dalam wilayah Kabupaten Tabalong, Soendjoto et al., (2005) mengungkapkan bahwa secara statistik, terdapat korelasi positif dan signifikan antara sumber air di hutan karet dan kehadiran bekantan. Pada kasus di hutan karet Desa
Simpung Layung ini, dapat diketahui lebih jauh bahwa sumber air tidak hanya merupakan titikawal bagi bekantan untuk memulai aktivitas pada siang hari atau titik-akhir untuk menghentikan aktivitas pada siang hari dan memulai tidur pada malam harinya, tetapi juga merupakan titik-antara untuk beraktivitas sosial (seperti bermain, istirahat, bertengkar).

Adanya titik antara menunjukkan perpindahan kelompok bekantan dua kali per hari. Perpindahan pertama terjadi dari sumber air tertentu yang dipergunakan sebagai lokasi tidur ke sumber air lain, tempat bekantan melakukan sebagian besar aktivitas pada siang hari. Perpindahan kedua terjadi dari sumber air untuk aktivitas siang ini ke sumber air berikutnya yang dipergunakan sebagai lokasi tidur pada malam harinya. Penjelasan ini memperkuat pendapat Bismark (1986a) bahwa pola pergerakan bekantan berorientasi pada lokasi tempat tidur, tempat makan, dan istirahat.

Tujuh puluh delapan kejadian $(69,03 \%)$ dari 113 kejadian yang diamati pada kelompok yang berasal dari HS serta $64(70,33 \%)$ dari 91 kejadian pada kelompok yang berasal dari HM, merupakan perpindahan antar-sumber air yang terjadi dua kali per hari. Kejadian atau prosentase sisanya hanya menunjukkan perpindahan satu kali sehari. Meskipun secara statistik perpindahan bekantan cenderung dua kali sehari daripada sekali sehari $\left(\chi^{2}=16,36\right.$; $p$ $<0,01$ untuk HS dan $\chi^{2}=15,04 ; \mathrm{p}<0,01$ untuk HM), perpindahan yang dilakukan bekantan dengan frekuensi sekali sehari masih merupakan pertanyaan; apakah bekantan juga melakukan perpindahan sekali sehari (selain dua kali sehari) atau memang selalu melakukannya dua kali per hari? Di lapangan data perpindahan sekali sehari ini diperoleh, ketika peneliti kehilangan jejak mengikuti bekantan, karena terhalang oleh kondisi lapangan.

Perpindahan antar-sumber air dilakukan oleh bekantan pada pagi, tengah, dan petang hari. Perpindahan lebih sering dilakukan pada jam 06.00-08.00 dan jam 15.00-17.00 serta jarang dilakukan pada jam 11.00-14.00 (Gambar 1). 


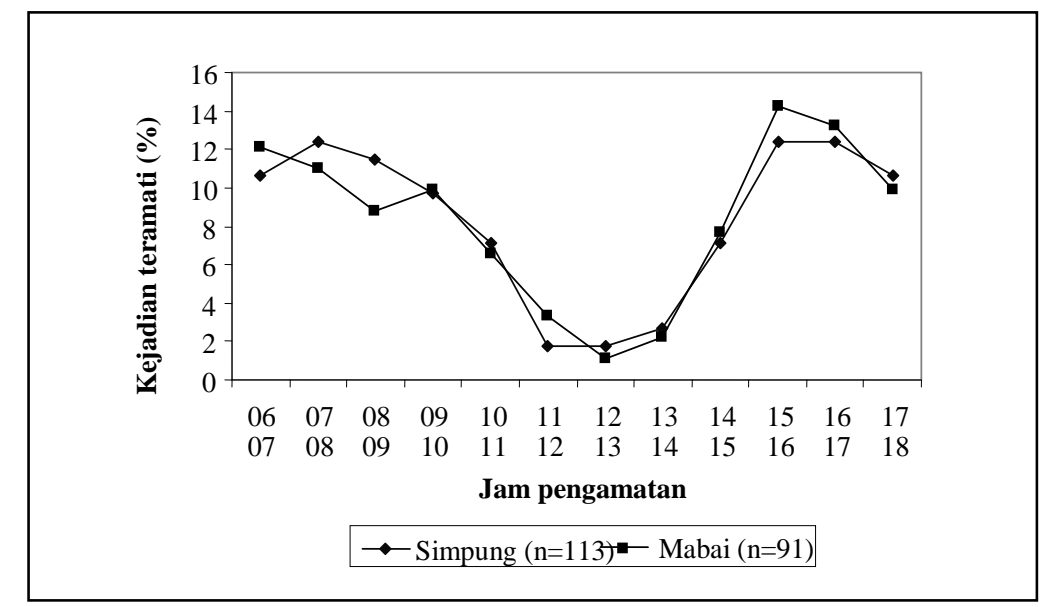

Gambar 1. Prosentase kejadian berpindah antar-sumberair oleh bekantan Hutan Simpung dan Hutan Mabai yang teramati antara jam 06.00-18.00 dalam periode pengamatan April 2003 - Juli 2004

Perpindahan dilakukan oleh bekantan dengan cara berjalan di atas tanah, berjalan di atas dahan, atau meloncat antara pepohonan. Primata berjalan di atas tanah, ketika menyusuri tepi sumber air yang kering pada musim kemarau, melewati tapak-tapak yang hanya ditumbuhi semak, menyeberang jalan Simpung Layung - Muara Uya, atau bahkan dalam vegetasi hutan yang rapat sekalipun. Bekantan menyeberangi jalan selebar 8-10 m ini (pal Kilometer 276 - 277) dari hutan di sebelah timur jalan ke Sungai Uwi. Penyeberangan jalan hanya dijumpai oleh peneliti pada musim kemarau, ketika tidak ada sedikit pun air di sumber air yang ada di hutan karet. Perpindahan dengan cara berjalan di atas dahan atau meloncat menimbulkan bunyi gaduh. Loncatan-loncatan bekantan bahkan dapat mematahkan dahan berdiameter $5 \mathrm{~cm}$. Bunyi patahan dahan serta gesekan ranting pepohonan yang dibarengi dengan lenguhan nguo.....okh dari jantan atau suara gaduh (yang didahului dengan salakan grukh) terdengar dari jarak $300 \mathrm{~m}$. Bunyi dan suara itu menandakan adanya perpindahan bekantan.

\section{Jarak Perpindahan dan Luas Daerah Jelajah}

Jarak rerata perpindahan harian bekantan adalah 541,24 m (kisaran 250 - 950). Jarak ini ditempuh dalam waktu rerata 1,68 jam (kisaran 0,64 - 4,04) atau kecepatan rerata 337,62 $\mathrm{m} / \mathrm{jam}$ (kisaran 233,89 - 472,71) (Tabel 1). Menurut Bismark (1986a, 1987a), jarak rerata perjalanan harian bekantan di hutan mangrove Taman Nasional Kutai 1.007,5 m (kisaran 450 - 1.750), sedangkan menurut Soerianegara et al., (1994), hanya 497,2 m (kisaran 200 1.100). Di hutan mangrove Samunsam, Salter et al., (1985) menghitung jarak rerata perpindahan harian $1.312 \mathrm{~m}$ (maksimum 1.550 $\mathrm{m}$ ) dengan kecepatan rerata $85 \mathrm{~m} / \mathrm{jam}$ (kisaran $0-450)$.

Tabel 1. Jarak, durasi, dan kecepatan perpindahan harian bekantan

\begin{tabular}{|c|c|c|c|c|c|c|c|c|c|}
\hline \multirow[t]{2}{*}{ Kelompok } & \multicolumn{3}{|c|}{ Jarak harian (m) } & \multicolumn{3}{|c|}{$\begin{array}{c}\text { Durasi berpindah antar-sumberair } \\
\text { (jam) }\end{array}$} & \multicolumn{3}{|c|}{ Kecepatan (m/jam) } \\
\hline & Rerata & Minimum & Maksimum & Rerata & Minimum & Maksimum & Rerata & Minimum & Maksimum \\
\hline Simpung & $\begin{array}{l}527,79 \\
(\mathrm{n}=18)\end{array}$ & 250 & 9950 & $\begin{array}{c}0,86 \\
(\mathrm{n}=36)\end{array}$ & 0,32 & 2,02 & $\begin{array}{l}315,21 \\
(\mathrm{n}=36)\end{array}$ & 206,90 & $4 \quad 461,54$ \\
\hline Mabai & $\begin{array}{l}554,69 \\
(\mathrm{n}=16)\end{array}$ & 300 & 950 & $\begin{array}{c}0,82 \\
(\mathrm{n}=32)\end{array}$ & 0,33 & 2,02 & $\begin{array}{l}360,03 \\
(n=32)\end{array}$ & 260,87 & 483,87 \\
\hline Gabungan & 541,24 & 250 & 950 & 0,84 & 0,32 & 2,02 & 337,62 & 233,89 & 472,71 \\
\hline
\end{tabular}

Catatan:

1) Jarak yang dihitung adalah jarak perpindahan harian (atau untuk perpindahan dua kali/hari)

2) Durasi dan kecepatan berpindah yang dihitung adalah kecepatan per kejadian pindah (atau per sekali berpindah antar-sumberair). Dengan demikian, rerata durasi perpindahan yang dilakukan dua kali dalam sehari adalah 2 x 0,84 jam atau 1,68 jam. 
Secara statistik, jarak perpindahan harian berkorelasi negatif dan signifikan dengan curah hujan $\left(I_{\mathrm{s}}=-0,58 ; \mathrm{p}<0,05 ; \mathrm{n}=14\right)$. Jarak itu menurun pada bulan-bulan dengan curah hujan cukup tinggi (musim hujan) dan menaik pada bulan-bulan dengan curah hujan rendah (musim kemarau) (Gambar 2).
Seperti satwa pada umumnya, bekantan berpindah terutama untuk menghadapi keterbatasan pakan dan air di lingkungan sekitarnya. Keterbatasan ini berkaitan dengan jumlah (banyak atau sedikit), keragaman jenis pakan, dan tempat perolehannya. Tempat yang menyediakan keragaman jenis pakan dan sekaligus dekat dengan air adalah baruh.

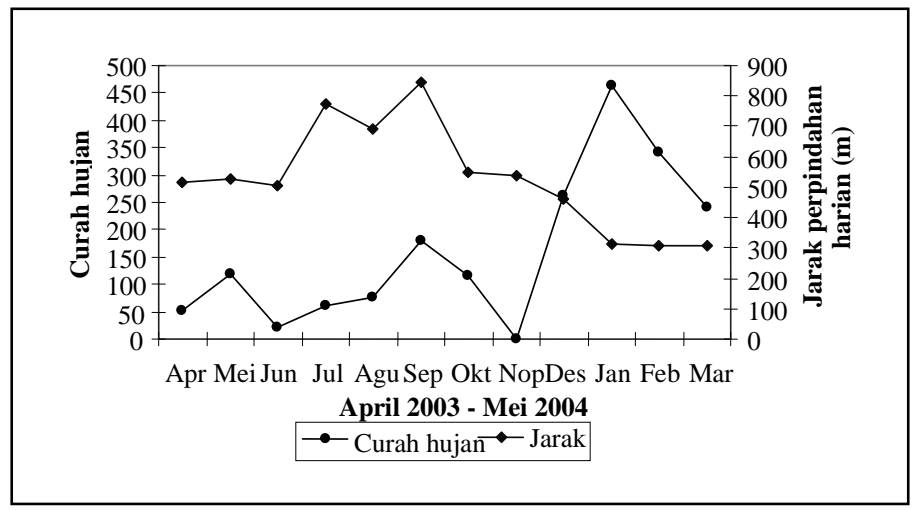

Gambar 2. Hubungan jarak perpindahan harian dengan curah hujan

Ketersediaan pakan dan air di baruh bergantung pada musim. Pada musim hujan, air di sumber air (terutama baruh dan sungai kecil di hutan karet) melimpah dan tetumbuhan hutan bertumbuh subur. Kemelimpahan sumberdaya mendorong bekantan untuk tidak berpindah jauh dari sumberdaya. Perpindahan yang terjadi adalah antara baruh tertentu ke baruh lain yang jarak berdekatan. Sebaliknya, pada musim kemarau air di sumber air tersebut menyusut. Bahkan pada kemarau panjang tidak ada air sama sekali di sumber air. Karet yang mendominasi habitat pun merontokkan daun, walaupun waktu perontokannya tidak bersamaan. Banyak di antara pepohonan bahkan hanya tampak dahan dan ranting saja. Pada kasus hutan karet Desa Simpung Layung, satu-satunya sumber air yang airnya masih melimpah adalah Sungai Uwi. Pada kondisi inilah bekantan menambah jarak perpindahan harian untuk memperoleh asupan air dan menjaga asupan jumlah dan keragaman pakan.

Perubahan jarak berarti perubahan daerah jelajah. Apabila diasumsikan jarak antara individu-individu sekelompok bekantan yang berada pada posisi paling luar dalam jalur pergerakan sekitar $25 \mathrm{~m}$, maka luas daerah jelajah rerata sekelompok bekantan per hari di hutan karet Simpung Layung adalah 1,353 ha (kisaran 0,625-2,375). Luasan ini merupakan daerah jelajah intensif, yaitu daerah jelajah yang benar-benar dimanfaatkan bekantan untuk beraktivitas atau berperilaku harian. Apabila dibandingkan dengan luas daerah jelajah bekantan yang dilaporkan oleh peneliti lain (Tabel 2), ukuran luas ini relatif kecil.

Perubahan jarak atau daerah jelajah tidak hanya disebabkan oleh musim yang mempengaruhi ketersediaan pakan dan air di sekitar baruh, tetapi juga oleh aktivitas manusia yang menyebabkan terjadinya mosaik-mosaik tutupan lahan dalam bentuk hutan karet, kebun, atau ladang. Mosaik-mosaik tersebut merupakan konsekuensi dari status lahan yang merupakan kawasan budidaya hutan karet Desa Simpung Layung berstatus kawasan budidaya (Soendjoto et al., 2003) dan kepenguasaan atau kepemilikan hutan karet oleh banyak orang atau kepala keluarga (KK). Ketika KK tertentu mengonversi hutan karetnya menjadi ladang, KK lain mengusahakan ladangnya menjadi kebun dan KK lainnya lagi masih tetap membiarkan hutan karetnya menghasilkan getah. Mosaik-mosaik ini memaksa bekantan mengubah atau menggeser jalur perpindahan. Selama perpindahan bekantan berupaya untuk mengikuti jalur bervegetasi (semak belukar, hutan) dan menghindari lokasi terbuka (seperti ladang). 
Tabel 2. Luas daerah jelajah bekantan di beberapa tipe dan lokasi habitat yang dilaporkan oleh beberapa peneliti

\begin{tabular}{|c|c|c|c|c|c|}
\hline No. & Peneliti & $\begin{array}{c}\text { Daerah } \\
\text { jelajah (ha) }\end{array}$ & $\begin{array}{l}\text { Pergerakan } \\
\text { harian }(\mathbf{m})\end{array}$ & $\begin{array}{c}\text { Tipe habitat dan } \\
\text { lokasi }\end{array}$ & Keterangan \\
\hline 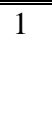 & "Salter et al. (1985) & 270 & $\begin{array}{c}1.312 \text { (maks. } \\
1.550)\end{array}$ & $\begin{array}{l}\begin{array}{l}\text { Riparian } \\
\text { (pesisir) }\end{array} \\
\text { Samunsam }\end{array}$ & " Laju rerata $85 \mathrm{~m} / \mathrm{jam}(0-450)$ \\
\hline 2 & Napier dan Napier (1986) & 130 & - & - & - \\
\hline 3 & Bismark (1980) & 27 & - & $\begin{array}{l}\text { Rawa gambut air } \\
\text { tawar TN } \\
\text { Tanjung Puting }\end{array}$ & - \\
\hline 4 & Bismark (1986b) & 100 & $500-1.200$ & $\begin{array}{l}\text { Hutan bakau TN } \\
\text { Kutai }\end{array}$ & $\begin{array}{l}3 \text { kel.; } 30-117 \text { ind.; } 350-550 \mathrm{~m} \text { dari } \\
\text { tepian sungai }\end{array}$ \\
\hline 5 & Bismark (1987a) & $\begin{array}{l}100,8 * \\
0,86 * *\end{array}$ & $\begin{array}{c}1.007,5 \\
(450-1.750)\end{array}$ & $\begin{array}{l}\text { Hutan bakau TN } \\
\text { Kutai }\end{array}$ & *Total 117 ind.; ** Rerata per ind. \\
\hline 6 & Bennett dan Sebastian (1988) & 900 & $\begin{array}{c}483 \\
(300-590)\end{array}$ & $\begin{array}{l}\text { Samunsam, } \\
\text { Serawak }\end{array}$ & $\begin{array}{l}\text { Asumsi: jarak jelajah terjauh dari } \\
\text { sungai ke daratan } 600 \mathrm{~m} \text {. Peneliti ini } \\
\text { berpendapat bahwa datanya cenderung } \\
\text { bias. Beberapa kejadian menunjukkan } \\
\text { bahwa pergerakan harian kel. harem } \\
\text { mencapai minimal } 1.125 \mathrm{~m} \text { dan kel. } \\
\text { semua-jantan } 1.700 \mathrm{~m} \text {. }\end{array}$ \\
\hline 7 & Yeager (1989) & $\begin{array}{c}19,3(18,1- \\
20,5) * ; \\
130,3(125- \\
137,5)^{* *}\end{array}$ & & $\begin{array}{l}\text { Rawa gambut air } \\
\text { tawar TN } \\
\text { Tanjung Puting }\end{array}$ & $\begin{array}{l}* \text { Rerata dan kisaran untuk setiap kel.; } \\
* * \text { untuk total empat kel. }\end{array}$ \\
\hline 8 & Soerianegara et al. (1994) & $\begin{array}{c}100 \text { (intensif } \\
19,4)\end{array}$ & $\begin{array}{c}497,2 \\
(200-1.100)\end{array}$ & $\begin{array}{l}\text { Hutan mangrove } \\
\text { TN Kutai }\end{array}$ & $90-400 \mathrm{~m}$ dari tepian sungai \\
\hline 9 & Alikodra (1997) & $\begin{array}{l}(15,47- \\
30,71)^{*} ; \\
66,28^{* *} \\
0,68^{* * *}\end{array}$ & $0-150$ & Samboja Koala & $\begin{array}{l}* \text { Untuk } 3 \text { kel. amatan; **Untuk total } \\
98 \text { ind.; ***Rerata per ind. }\end{array}$ \\
\hline 10 & Supriatna dan Wahyono (2000) & $50-270$ & $>1.500$ & - & - \\
\hline
\end{tabular}

Catatan: 1) Kel. = kelompok; ind. = individu; TN = Taman Nasional; maks = maksimum.

2) Angka di dalam tanda kurung menyatakan kisaran minimum-maksimum.

Daerah intensif adalah daerah inti.

\section{Proporsi Waktu Berperilaku dan Pemanfaatan Strata Pohon}

Dalam aktivitas hariannya (berdasarkan lama pengamatan $12 \mathrm{jam} / \mathrm{hari}$ ), $14 \%$ (rerata 1,68 jam; kisaran 0,64-4,04) dipergunakan untuk berpindah dari sumber air tertentu ke sumber air lainnya, dan $86 \%$ (rerata 10,32 jam; kisaran 11,36-7,96) untuk menetap pada sumber air tertentu. Dari durasi menetap ini, $41,30 \%$ dipergunakan untuk makan, 40,66\% untuk istirahat, $15,64 \%$ untuk bermain, dan sisanya $(2,40 \%)$ untuk menyelisik. Sebagai perbandingan, pada Tabel 3 disajikan proporsi waktu perilaku bekantan yang ditemukan oleh peneliti lain.

Tabel 3. Proporsi waktu dalam aktivitas-harian bekantan

\begin{tabular}{|c|c|c|c|c|c|c|c|c|c|c|}
\hline \multirow[t]{2}{*}{ No. } & \multirow{2}{*}{$\begin{array}{c}\text { Jam } \\
\text { Penelitian }\end{array}$} & \multicolumn{8}{|c|}{ Proporsi Waktu (\%) } & \multirow[t]{2}{*}{ Sumber } \\
\hline & & Makan & Istirahat & Berpindah & Bermain & $\begin{array}{c}\text { Menyeli } \\
\text { sik }\end{array}$ & $\begin{array}{c}\text { Agoni } \\
\text { stik }\end{array}$ & $\begin{array}{c}\text { Interaksi } \\
\text { Sosial }^{1)} \\
\end{array}$ & $\begin{array}{r}\text { Lain- } \\
\text { lain } \\
\end{array}$ & \\
\hline 1 & Siang hari & 50,0 & 25,0 & 25,0 & 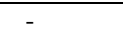 & 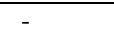 &  & 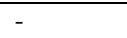 & 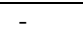 & Salter dan Aken (1983) \\
\hline \multirow[t]{2}{*}{2} & $0600-1900$ & 11,1 & 58,4 & 27,0 & - & - & - & 2,4 & 1,1 & $\begin{array}{l}\text { Salter et al. (1985) di SM } \\
\text { Samunsam }\end{array}$ \\
\hline & & 50,5 & 25,7 & 22,7 & - & - & - & 1,0 & 0,1 & Salter et al. (1985) di TN Bako \\
\hline 3 & Siang hari & 27,9 & 52,2 & 19,9 & - & - & - & - & - & Bismark (1987a, 1987b) \\
\hline 4 & $0530-1845$ & 34,25 & 33,33 & 23,18 & 4,76 & 1,28 & 2,75 & - & - & Alikodra dan Mustari (1994) \\
\hline 5 & $0500-1900$ & 23,39 & 45,03 & 21,64 & - & - & - & - & - & Alikodra (1997) \\
\hline 6 & $0600-1800$ & 41,30 & 40,66 & - & 15,64 & 2,43 & - & - & - & Hasil penelitian ini ${ }^{2)}$ \\
\hline
\end{tabular}

Catatan:

1) Interaksi sosial dalam pengertian umum.

2) Proporsi waktu diamati selama bekantan menetap atau tidak dalam posisi sedang berpindah 
Gambar 3 menunjukkan bahwa waktu makan lebih banyak dilakukan pada pagi hari (jam 06.00-09.00) dan sore hari (jam 15.0018.00). Sebagai primata diurnal, bekantan perlu makan pada pagi hari sebagai upaya untuk memperoleh energi yang selanjutnya dipergunakan dalam aktivitas siang (bermain, menyelisik, istirahat), sedangkan makan pada sore hari untuk memperoleh energi yang dipergunakan 1) sebagai pengganti energi yang dikeluarkan dalam aktivitas siang dan 2) sebagai cadangan dalam aktivitas malam (tidur, berjaga atas predator). Alokasi waktu makan pada bekantan, terjadi juga pada monyet Macaca sinica aurifrons. Menurut Vandercone \& Santiapillai (2003), monyet M.s. aurifrons lebih giat mencari pakan pada pagi (jam 07.0010.45) dan sore hari (14.30-16.00) serta berkurang pada tengah hari (12.00-14.00).

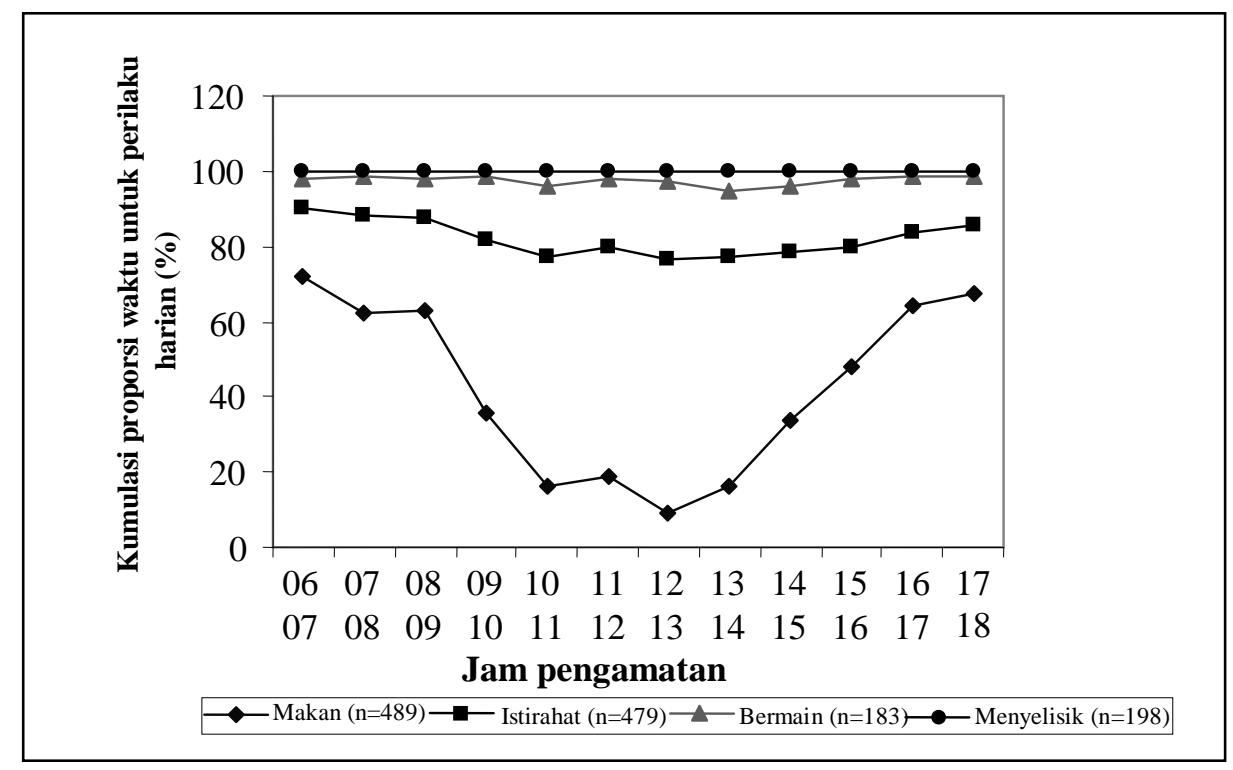

Gambar 3. Kumulasi proporsi waktu berperilaku harian menurut jam pengamatan

Istirahat lebih banyak dilakukan pada tengah hari (jam 09.00-15.00). Bekantan tidak menguras energi untuk 1) bergerak atau berpindah secara berlebihan dan 2) menghadapi tingginya suhu atau rendahnya kelembaban udara, tetapi memanfaatkannya untuk keperluan lain. Istirahat tengah hari merupakan reaksi terhadap suhu yang semakin panas (Alikodra, 1997), dan merupakan upaya sangat penting bagi primata folivora untuk mengerahkan energi memperlancar proses fermentasi dalam pencernaan makanan (Bismark, 1986a). Menurut Boonratana (2000), dengan beristirahat bekantan merilekskan ototototnya.

Berdasarkan pada strata pohon (Gambar 4 ), sebagian besar proporsi waktu $(84,01 \%)$ lebih banyak dihabiskan untuk berperilaku pada level ketinggian di bawah $15 \mathrm{~m}$. Dari proporsi waktu itu, 34,49\% untuk beristirahat, $32,65 \%$ makan, $14,91 \%$ bermain, dan $1,97 \%$ menyelisik. Secara statistik, strata pohon berpengaruh signifikan terhadap makan $\left(\chi^{2}=\right.$ $43,26 ; \mathrm{p}<0,01 ; \mathrm{db}=3 ; \mathrm{n}=489)$, beristirahat $\left(\chi^{2}=82,38 ; \mathrm{p}<0,01 ; \mathrm{db}=3 ; \mathrm{n}=479\right)$, dan bermain $\left(\chi^{2}=51,25 ; \mathrm{p}<0,01 ; \mathrm{db}=3 ; \mathrm{n}=\right.$ 183), tetapi tidak berpengaruh terhadap kegiatan menyelisik $\left(\chi^{2}=5,07 ; \mathrm{p}<0,01 ; \mathrm{db}=\right.$ $3 ; \mathrm{n}=198)$.

Pengaruh strata pohon terhadap makan, istirahat, dan bermain disebabkan oleh dua faktor. Pertama, ketersediaan dan keberagaman pakan tidak hanya tersedia pada spesies tumbuhan yang tingginya lebih dari $15 \mathrm{~m}$, tetapi juga dipenuhi oleh spesies dengan tinggi kurang dari $15 \mathrm{~m}$. Spesies tumbuhan yang tingginya lebih dari $15 \mathrm{~m}$ antara lain adalah karet yang merupakan tumbuhan dominan, tiwadak (Artocarpus integer), tiwadak banyu (A. teysmanii), tarap (A. elasticus), dan sungkai (Peronema canescens), sedangkan yang tingginya kurang dari $15 \mathrm{~m}$ antara lain adalah 
kujamas (Syzygium stapfiana), serai merah ( $S$. pyrifolium), salam ( $S$. polyanthum), mampat (Cratoxylum cochinchinensis), dan geminting (Symplocos cochinchinensis). Karena dianggap tidak berguna, spesies dengan tinggi kurang dari $15 \mathrm{~m}$ biasanya ditebangi. Penebangan atau penebasan dilakukan terutama pada hutan karet yang akan dimanfaatkan (disadap). Namun, spesies ini cepat tumbuh dan menjadikan hutan heterogen kembali.

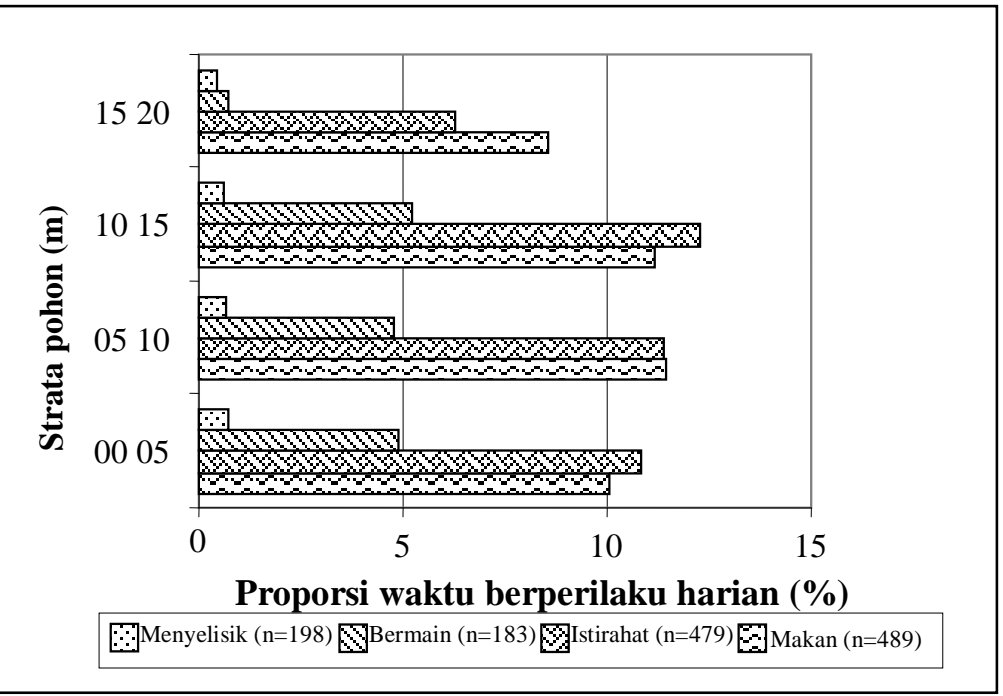

Gambar 4. Proporsi waktu berperilaku harian menurut strata pohon

Kedua, pada level ketinggian kurang dari $15 \mathrm{~m}$ percabangan (dari berbagai spesies tumbuhan) banyak terbentuk dan dedaunan lebih merimbun. Kondisi ini tidak hanya menciptakan iklim mikro yang nyaman bagi bekantan untuk duduk istirahat atau bermain, tetapi juga menyediakan tempat yang aman untuk menghindar dari kejaran sesama bekantan dalam kasus pertengkaran, bersembunyi atau melarikan diri dari predator, dan berlindung dari terik matahari. Pohon yang biasa dipergunakan untuk aktivitas itu antara lain mahang (Macaranga pruinosa), alaban (Vitex pubescens), galigantan (Dillenia exelsa), dan bangkinang burung (Elaeocarpus stipularis). Menurut Bismark (1986a), kerimbunan daun dan kedekatan dengan sumber air bermanfaat untuk menjaga kestabilan suhu tubuh. Menurut Soedargo (1995), monyet ekor panjang di Pulau Tinjil banyak beraktivitas pada ketinggian 10-15 m, karena pada ketinggian itu pakan terkonsentrasi dan monyet pun terlindung dari terik matahari secara langsung dan terhindar dari serangan predator.

Kedua faktor tersebut diperkuat oleh dua kerugian yang dapat ditimbulkan oleh perilaku pada ketinggian lebih dari $15 \mathrm{~m}$. Pertama, jatuh dari ketinggian di atas $15 \mathrm{~m}$ menyebabkan resiko trauma yang lebih parah. Walaupun kemungkinan terjadinya termasuk jarang, jatuh dari ketinggian bukan kejadian mustahil pada bekantan. Jatuh dapat terjadi, terutama ketika bekantan sedang tidur, bermain (saling mengejar, bergelantungan), atau terkejut. Dalam suasana sunyi (misalnya, ketika sebagian besar anggota kelompok sedang istirahat atau tidur tengah hari), jatuhnya bekantan sering mengejutkan anggota kelompok dan menimbulkan suasana gaduh. Kedua, bergerak ke ketinggian lebih dari $15 \mathrm{~m}$ membutuhkan lebih besar energi. Oleh sebab itu, bekantan lebih memilih sediaan energi (dalam bentuk pakan) yang jumlahnya melimpah pada ketinggian kurang dari $15 \mathrm{~m}$ daripada sediaan yang ada pada ketinggian lebih dari $15 \mathrm{~m}$ tetapi jumlahnya sedikit.

\section{Kesimpulan dan Saran}

Sumber air yang berupa baruh merupakan pusat aktivitas bekantan di hutan karet Desa Simpung Layung. Perpindahan terjadi antar-baruh dan sebagian besar perpindahan dilakukan dengan frekuensi dua 
kali sehari. Perpindahan biasanya dilakukan pada pagi dan petang hari serta jarang dilakukan pada tengah hari.

Selama menetap di dekat sumber air, proporsi waktu untuk makan hampir sama dengan untuk istirahat. Makan dilakukan pada pagi dan sore hari, sedangkan istirahat pada tengah hari. Makan, istirahat, dan bermain dipengaruhi oleh strata pohon.

Penelitian masih perlu dilanjutkan untuk mempelajari pakan, terutama yang mencakup jenis, jumlah, dan kandungan nutrisinya.

\section{Daftar Pustaka}

Alikodra, H.S. and Mustari, A.H. 1994. Study on Ecology and Conservation of Proboscis Monkey (Nasalis larvatus Wurmb) at Mahakam River Delta, East Kalimantan: Behaviour and Habitat Function. Annual Report of Pusrehut 5: 28-38.

Alikodra, H.S. 1997. Populasi dan Perilaku Bekantan (Nasalis larvatus) di Samboja Koala, Kalimantan Timur. Media Konservasi 5(2): 67-72.

Bennett, E.L. and Sebastian, A.C. 1988. Social Organization and Ecology of Proboscis Monkeys (Nasalis larvatus) in Mixed Coastal Forest in Sarawak. Inernational Journal of Primatology 9(3): 233-255.

Bismark, M. 1980. Populasi dan Tingkahlaku Bekantan (Nasalis larvatus) di Suaka Margasatwa Tanjung Puting, Kalimantan Tengah. Laporan Lembaga Penelitian Hutan No. 357, Bogor.

Bismark, M. 1986a. Aktivitas dan Pola Pergerakan Harian Bekantan di Hutan Bakau Taman Nasional Kutai. Buletin Penelitian Hutan (476): 31-45.

Bismark, M. 1986b. Studi Habitat dan Tingkahlaku Bekantan (Nasalis larvatus) di Taman Nasional Kutai. Buletin Penelitian Hutan (474): 67-79.

Bismark, M. 1987a. Sosio Ekologi Bekantan (Nasalis larvatus) di Taman Nasional Kutai, Kalimantan Timur. Rimba Indonesia 21(2-4): 24-35.

Bismark, M. 1987b. Strategi dan Tingkahlaku Makan Bekantan (Nasalis larvatus) di Hutan Bakau, Taman Nasional Kutai, Kalimantan Timur. Buletin Penelitian Hutan (492): 1-10.
Boonratana, R. 2000. A Short Note on Vigilance Exhibited by Proboscis Monkey (Nasalis larvatus) in the Lower Kinabatangan, Sabah, Malaysia. Tigerpaper 27(4): 21-22.

Martin, P. and Bateson, P. 1987. Measuring Behaviour. An Introductory Guide. Cambridge University Press, Cambridge.

Napier, J.R. and Napier, P.H. 1986. The Natural History of the Primates. MIT Press, Cambridge.

Salter, R.E. and Aken, K.M. 1983. The Probocis Monkey in Bako National Park, Sarawak. Tigerpaper 10(3): $6-8$

Salter, R.E., MacKenzie, N.A., Nightingale, N., Aken, K.M. and Chai, P.K.P. 1985. Habitat Uses, Ranging Behaviour, and Food Habitats of the Proboscis Monkey, Nasalis larvatus (van Wurmb), in Sarawak. Primates 26(4): 436451 .

Soedargo, S. 1995. Studi Vegetasi di Habitat Monyet Ekor Panjang (Macaca fascicularis Raffles, 1821) di Pulau Tinjil. Media Konservasi 4(4): 247-254.

Soendjoto, M.A., Alikodra, H.S., Bismark, M. dan Setijanto, H. 2003. Persebaran dan Status Habitat Bekantan (Nasalis larvatus) di Kabupaten Tabalong, Kalimantan Selatan. Media Konservasi 8(2): 45-51.

Soendjoto, M.A., Alikodra, H.S., Bismark, M. dan Setijanto, H. 2005. Hubungan Kehadiran Bekantan (Nasalis larvatus) dengan Perairan Hutan Karet di Kabupaten Tabalong, Kalimantan Selatan. Biodiversitas 6(1): 4044.

Soerianegara, I., Sastradipradja, D., Alikodra, H.S. dan Bismark, M. 1994. Studi Habitat, Sumber Pakan, dan Perilaku Bekantan (Nasalis larvatus) sebagai Parameter Ekologi dalam Mengkaji Sistem Pengelolaan Habitat Hutan Mangrove di Taman Nasional Kutai. Laporan Akhir Pusat Penelitian Lingkungan Hidup, IPB, Bogor.

Supriatna, J. dan Wahyono, E.H. 2000. Panduan Lapangan Primata Indonesia. Yayasan Obor Indonesia, Jakarta.

Vandercone, R. and Santiapillai, C. 2003. Feeding Ecology and Factors Influencing the Range of the Dusky Toque Monkey (Macaca sinica aurifrons) in Udawattakelle Sanctuary, Sri Lanka. Tigerpaper 30(3): 20-27.

Yeager, C.P. 1989. Feeding Ecology of the Proboscis Monkey (Nasalis larvatus). Inernational Journal of Primatology 10(6): 497-530. 